\title{
Isolation of Jatropha Curcas Seeds Isolectins with Variable Affinity for Human and Animal Blood Types
}

\author{
Abeer Al Gaali ${ }^{1}$, GadAllah Modawe ${ }^{2}$, Reem M. Ahmed ${ }^{3}$, and Emadeldin H. E. \\ Konozy ${ }^{3}$
}

\begin{abstract}
${ }^{1}$ Ahfad University for Women, Faculty of pharmacy, Department of Pharmaceutical biotechnology ${ }^{2}$ Omdurman Islamic university, Faculty of Medicine and Health Sciences, Biochemistry Department, Khartoum, Sudan

${ }^{3}$ Biotechnology Department, Africa city of technology, Khartoum, Sudan
\end{abstract}

Corresponding Author: Emadeldin H. E. Konozy; Phone: +249 (0) 912387107 email: ehkonozy@yahoo.com

Received 23 August 2019 Accepted 14 December 2019

Published 30 December 2019

Production and Hosting by Knowledge E

(c) Abeer Al Gaali et al. This article is distributed under the terms of the Creative

Commons Attribution

License, which permits

unrestricted use and

redistribution provided that the original author and source are credited.

Editor-in-Chief:

Prof. Mohammad A. M. Ibnouf

\section{Abstract}

Background: Lectins are carbohydrate-binding protein which agglutinate glycoconjugates in a reversible way, they are with wide applications in biological and medical sciences. Jatropha curcas belongs to the family euphorbiaceae and is distributed in many tropical and subtropical countries. The toxicity of this plant is known for long ago and has been attributed to several components among which is a protein called curcin.

Methods: Jatropha curcas seeds were pulverized and protein was extracted with suitable buffer. Protein extract thus obtained had undergone successive protein precipitations by salting-out using $\left(\mathrm{NH}_{4}\right)_{2} \mathrm{SO}_{4}$ (AS) at 40,60 , and $80 \%$ saturations. Lectin activity was detected by hemagglutination method using human- and animal blood types. AS-precipitated protein fractions that possess lectin activity were tested for their antimicrobial activity against the pathogenic Staphylococcus aureus, Escherichia coli, Bacillus aueras, and Candida albicans.

Results: At least three isolectins (Lec40, Lec60, and Lec80) were detected by hemagglutination ( $\mathrm{HA}$ ) and isolated by AS fractionation from the crude Jatropha curcas seed extract (CExt). The isolectins exhibited different tendency toward human and animal blood types. None of the isolectins could inhibit any of the used bacterial strains and Candida albicans.

Conclusions: In this study, though the detected lectins resemble their counterpart legume lectins, they, however, showed apparently unique and variable behavior toward human and animal blood types. Which might emphasize on the need for further structural analysis on the affinity sites of these proteins.

Keywords: Jatropha curcas; euphorbiaceae; lectin; hemagglutination; antimicrobial activity

\section{G OPEN ACCESS}




\section{Introduction}

Lectins are carbohydrate-binding proteins that recognize and bind reversibly to specific mono and oligosaccharides on cell surfaces, the extra cellular matrix, and secreted glycoprotein [1]. Due to lectin selective glycoconjugates binding property they have gained much of scientists' attention [2]. Plant lectins have been routinely used in research as a tool for glycoconjugates purification, and as bioactive agents for exploring some particular processes in cells or organisms. The current progress in plant lectin research, especially with respect to the study of the structure/ specificity/ function relationships of the different lectin categories will certainly refine and extend these molecules applications with emphasis to biomedical uses [3]. Much like other members of the family Euphorbiaceae, members of the genus Jatropha contain several toxic compounds [4]. In particular, the seeds contain the highly poisonous curcin, a dimeric lectin [5]. However, though of Jatropha apparent toxicity, its different parts have been used as medicine in certain geographic region [6] and is shown to exhibit antimicrobial activities [7]. Lectins have long been proven to be quite useful for clinical blood typing and structural studies of blood group substances [8]. The use of lectins as a tool for blood typing is known for years ago. In our laboratory, we have detected more than a single lectin in the seeds of Jatropha curcas and since no work has been done to characterize the affinity of these lectins towards human and animal blood types, this work was undertaken. Furthermore, since the previous work on the antimicrobial activity of $J$. curcas was focused on secondary metabolites we intended to fractionate seeds protein and study their antimicrobial effects on pathogenic bacterial and yeast strains.

\section{Methods}

Good and mature Jatropha curcas seeds were brought from North Kordofan state, Khartoum, Sudan.

\subsection{Erythrocytes}

Human blood samples (A, B, AB and O) were obtained from Blood Bank of Aldwali Hospital, Khartoum, Sudan. While animals blood (cow, goat, donkey and sheep) were obtained from Veterinary Hospital Bahri University, Khartoum, Sudan. 


\subsection{Protein estimation}

Protein content was determined according to ref [9] using bovine serum albumin (BSA) as the standard.

\subsection{Preparation of defatted acetone dried powder (ADP)}

Jatropha curcas seeds were ground by coffee blender to obtain fine powder. Seeds powder was defatted with $500 \mathrm{~mL}$ petroleum ether and dehydrated with cold acetone and left at room temperature for drying. The obtained acetone dried powder (ADP) was quantified and used for protein extraction.

\subsection{Preparation of crude extract (CExt)}

To thirty five gram of the ADP, $170 \mathrm{~mL}$ of child physiological saline (0.145M) (PhS) was added and extracted for four hours under cold conditions. The extract was filtrated through cheesecloth. The clear protein supernatant obtained after removal of small cell debris by centrifugation was named as crude extract (CExt). Hemagglutination unit and specific activity were calculated for CExt and further fractions as described earlier [10].

\subsection{Ammonium sulphate (AS) protein fractions preparation}

CExt protein was subjected to varying successive fractionations by addition of solid AS at $40 \%, 60 \%$, and $80 \%$ saturations [11]. Precipitated proteins by salting-out were dissolved in minimal amount of PhS. The resultant protein fractions obtained after the suspension of precipitates in PhS were denoted here forth as Fr40, 60, and 80 , respectively. And the lectin activities detected in these AS fractions were named as Lec40, 60, and 80 respectively.

\subsection{Characterization of Fr40, 60 , and 80}

\subsubsection{Erythrocytes suspension}

Collected EDTA-treated blood samples (Human and animal) were taken, washed with several folds of $\mathrm{PhS}, 2 \%(\mathrm{v} / \mathrm{v})$ erythrocytes suspension were prepared in physiological saline $(0.145 \mathrm{M})$. Trypsinized erythrocytes were prepared by addition of $0.05 \%$ trypsin to 
RBCs suspension and the mixer was incubated at $37^{\circ} \mathrm{C}$ for an hour. Trypsinized RBCs were washed with four folds of PhS. Final RBCs suspension at $2 \%(v / v)$ was prepared as previously shown and used for all assays.

\subsubsection{Hemagglutination Activity Assay (HA)}

Hemagglutination test was performed in ELISA 96-well microtiter (U-shaped) plates, in a final volume of $100 \mu \mathrm{L}$. Agglutination was assessed after one hour incubation at room temperature. Hemagglutinating activity was expressed as titer, namely, the reciprocal of the highest dilution that gave a clear agglutination. The specific hemagglutinating activity was defined as titer (unit) per mg protein $[12,13]$.

\subsubsection{Anti-microbial activity of protein fractions}

For the disc diffusion antimicrobial tests, the test pathogens (100 $\mu \mathrm{L} /$ plate) (Table 1) were spread on Muller Hinton agar plates. Sterile paper discs of $(6 \mathrm{~mm}$ diameter, 0.09 $\mathrm{mm}$ thickness, 5 discs/plate) were aseptically transferred on agar plates and were then soaked with equal volume $5 \mu \mathrm{L}$ of $0.2 \mathrm{~g} / \mathrm{mL}(\mathrm{w} / \mathrm{v})$ fixed concentration of lec40, 60 , and 80. The zone of inhibition was examined after the plates were incubated at $37^{\circ} \mathrm{C}$ for 24-48 $\mathrm{h}$. The pathogens were also tested with both a standard antibiotic tetracycline (30 $\mu \mathrm{g}$ as positive control) and negative controls (solvents) [14].

\section{Results and Discussion}

50 gram of Jatropha curcas seeds were pulverized and extensively defatted with petroleum ether and extracted with suitable amount of PhS. The obtained clear protein solution was fractionated by the classical salting out technique using AS salt at 40 , 60 and $80 \%$ saturations. The resultant precipitants were dissolved in minimal amount of PhS. Almost equal quantities of protein was precipitated in each AS fraction. Upon testing these fractions for lectin activity by $\mathrm{HA}$, each faction exhibited detectable hemagglutinating activity, indicating the presence of lectin in multiform. These findings are similar to the one obtained by Osman et al [12] from seed extract of Tamarindus indica [12]. Whereas in contrary to De Oliveira et $a$ in which only one lectin was present in seeds [15]. Maximum lectin activity was detected in Fra80 followed by Fra60 and finally Fra40. By this step the isolectin collectively were purified by almost 10 times (Table 2). Precipitation of euphorbiaceae family lectins with salting out using AS is reported in 
several publications [16-19]. However, none of these groups detected the presence of isolectins separated by their order of AS solubility. These results could be attributed to the fact that in these reports CExt was brought in a single addition of AS to 60 [20] and 100\% saturations [21] and no systematic protein fractionation, as in the current investigation, was done. Moreover, since lec40 is none reactive towards human blood types, these authors might have missed its detection. The affinity purified toxic lectin, curcin, from J. curcas seeds, was initially precipitated from its crude extract by AS at $60 \%$ saturation. Single lectin, the curcin, was obtained with a pl 8.54 [20]. Whereas a $p$ of 4.4 for a single lectin from the latex of Synadenium carinatum was reported [22].

\subsection{Behavior of lectin toward human and animals blood types}

Of the several distinct properties of lectins is their erythrocytes Hemagglutinating Therefore, it's routine laboratory work to detect lectin activity by the hemagglutinating assay. Most researchers have focused their research on human erythrocytes $A B O$ system antigens [23] which could be due to their ease to obtain and higher stability in comparison to animal erythrocytes. All human ( $A, A B, B$ and $O$ ) or animal (cow, goat, horse and sheep) blood types were either used raw or trypsin-treated. The lectin isoforms (Lec40, Lec60, and Lec80) exhibited variable interaction patterns with the blood types used. Like most of other euphorbiaceae lectins, J. curcas seed lectins agglutinated human and animal bloods differently. Lec60 and 80 agglutinated poorly human $\mathrm{A}, \mathrm{B}$ and $\mathrm{O}$ blood types, whereasLec40 didn't clump any of the used human blood type. Interestingly, none of these isolectins could agglutinate $A B$ blood type. On the other hand, agglutination was induced or enhanced when human blood types were treated with trypsin (Table 3). Treatment of RBCs with proteases such as trypsin, neuraminidase, pronase, and papin is known to increase sensitivity of RBCs agglutination by several folds. Treatment of RBCs with protease leads to the removal of polypeptides on the surface of erythrocytes and exposing number of lectins surface receptors [24]. These preferential agglutinations of human blood types with this lectin confirm the presence of this lectin in multiform. Our results of agglutination of human blood types with Jatropha curcas isolectins, are in accordance with some published papers on euphorbiaceae family lectins $[18,19]$ whereas in contrary to some other reports [21]. These differences might highlight interesting variability in the affinity sites of these isolectins and through some light 
on the apparent distinct, thought yet to be disclosed, physiological role of these proteins.

When blood of animals like cow, goat, horse and sheep were used, none were agglutinated by jatropha curcas isolectins. However, interestingly, upon treatment of RBCs with trypsin, lec40 could only agglutinate, to good extend, cow and sheep bloods, whereas no effect was shown by lec60 and 80 (Table 3). Jawada et $a$ in their work E. tithymaloides leaves lectin had shown that among the different animal blood types they used, only cow erythrocytes were agglutinated [21]

\subsection{Antimicrobial activity of lectin}

The evaluation of the antimicrobial activity of Lec40,60 and 80 was conducted using 3 strains of bacteria, in which two were gram negative, one was gram positive and fungi cultivated in Mueller - Hinton medium, with different concentrations of protein 100 200 and 300ug, the antibiotic gentamycin was used as control. None of the isolectins lec30, 60 or 80 showed any inhibitory effect against the used bacterial and fungal strains (data not shown). A lectin from E. helioscopia was shown to express strong inhibitory effect on pseudomonas aeruginosa, klebsiella pnuemoniae and Escherichia coli [25]. Previous work with Jatropha curcas seed extract had shown inhibitory effect of J. curcas extract against Fusarium oxysporum however, since they didn't use Candida albicana, which we used in the present study, we couldn't correlate our results with theirs [14]

\section{Conclusion}

Though Jatropha curcas seed lectin is a typical legume family lectin in term of its presence in multiform, these lectins behaves differently from other lectins of the same family. With regards to RBCs hemagglutination, unlike majority of legume lectin, Jatropha curcas seed lectins agglutinated poorly tyrosinated or untyrosinated human and animal RBCs. These results conclusively indicate the peculiar active site of these proteins. Therefore, further studies on the affinity site of these lectins as well as their secondary and tertiary structure may pave explaining these interesting features of these proteins. 


\section{Abbreviations used}

AS: Ammonium sulphate

Fr40: Protein precipitate obtained after $40 \%$ AS saturation of crude extract

Fr60: Protein precipitate obtained after 60\% AS saturation of crude extract

Fr80: Protein precipitate obtained after $80 \%$ AS saturation of crude extract

Lec40: Lectin activity detected in protein fraction precipitated at $40 \%$ AS saturation

Lec60: Lectin activity detected in protein fraction precipitated at $60 \%$ AS saturation

Lec80: Lectin activity detected in protein fraction precipitated at $80 \%$ AS saturation

HA: Hemagglutination

CExt: Jatropha curcas seeds crude extract

ADP: Acetone dried powder

PhS: Physiological saline (0.145M)

NA: No agglutination observed

TABLE 1: The standard microorganism used in the assay.

Organism
Bacillus subtilis
Escherichia coli
Staphylococcus aureus
Candida albicans

Standard Code
NCTC 8236 (Gram +ve bacteria)
$\begin{array}{ll}\text { ATCC } 25922 & \text { (Gram -ve bacteria) } \\ \text { ATCC } 25923 & \text { (Gram +ve bacteria) } \\ \text { ATCC } 7596 & \end{array}$

TABLE 2: Partial purification of isolectins from Jatropha curcas seeds.

\begin{tabular}{l|c|c|c|c|c|c} 
Stage & $\begin{array}{c}\text { Total } \\
\text { volume }(\mathrm{mL})\end{array}$ & $\begin{array}{c}\text { Total } \\
\text { protein }(\mathrm{mg})\end{array}$ & $\begin{array}{c}\text { Lectin } \\
\text { Activity } \\
\text { (Unit) }\end{array}$ & $\begin{array}{c}\text { Activity } \\
\text { (Unit/mL) }\end{array}$ & $\begin{array}{c}\text { Specific } \\
\text { activity } \\
\text { (Unit/mg) }\end{array}$ & $\begin{array}{c}\text { Purification } \\
\text { Fold }\end{array}$ \\
\hline CExt & 100 & 70 & 16 & 160 & 11 & 1 \\
\hline Lec40 & 5 & 3 & 4 & 20 & 6 & 2 \\
\hline Lec60 & 5 & 3 & 16 & 80 & 32 & 3 \\
\hline Lec80 & 7 & 3 & 16 & 112 & 40 & 3
\end{tabular}

Trypsin-treated B blood was used for all assays 
TABLE 3: Agglutination study of lec40, 60 and 80 of Jatropha curcas with human and animal erythrocytes.

\begin{tabular}{|c|c|c|c|c|}
\hline \multicolumn{2}{|c|}{ Blood Type } & \multicolumn{3}{|c|}{ Hemagglutination activity titer (Unit) } \\
\hline \multicolumn{2}{|c|}{ Human } & Lec40 & Lec60 & Lec80 \\
\hline \multirow[t]{4}{*}{ Trypsin-untreated } & A & NA* & $2^{2}$ & 2 \\
\hline & $A B$ & NA & NA & NA \\
\hline & $\mathrm{B}$ & NA & $2^{2}$ & 2 \\
\hline & $\mathrm{O}$ & NA & $2^{2}$ & $2^{4}$ \\
\hline \multirow[t]{4}{*}{ Trypsin-Treated } & A & $2^{2}$ & $2^{4}$ & $2^{4}$ \\
\hline & $A B$ & $2^{4}$ & $2^{4}$ & $2^{4}$ \\
\hline & B & NA & $2^{4}$ & $2^{4}$ \\
\hline & $\mathrm{O}$ & NA & $2^{4}$ & $2^{4}$ \\
\hline \multicolumn{2}{|c|}{ Animal } & Lec40 & Lec60 & Lec80 \\
\hline \multirow[t]{4}{*}{ Trypsin-untreated } & Cow & NA & NA & NA \\
\hline & Goat & NA & NA & NA \\
\hline & Horse & NA & NA & NA \\
\hline & sheep & NA & NA & NA \\
\hline \multirow[t]{4}{*}{ Trypsin-Treated } & Cow & $2^{3}$ & NA & NA \\
\hline & Goat & NA & NA & NA \\
\hline & Horse & NA & NA & NA \\
\hline & sheep & $2^{4}$ & NA & NA \\
\hline
\end{tabular}

${ }^{*} \mathrm{NA}=$ no agglutination.

\section{References}

[1] Giacometti, J. (2015). Plant lectins in cancer prevention and treatment. Medicina Fluminensis, vol. 51, pp. 211-229.

[2] Van Damme, E. J. M. (2014). History of plant lectin research. In: J. Hirabayashi (eds.) Lectins: Methods in Molecular Biology (Methods and Protocols), vol 1200. New York, NY: Humana Press.

[3] Jiang, Q. -L., Zhang, S., Tian, M., et al. (2015). Plant lectins, from ancient sugarbinding proteins to emerging anti-cancer drugs in apoptosis and autophagy. Cell Proliferation, vol. 48, pp. 17-28.

[4] Devappa, R. K., Makkar. H. P., and Becker, K. (2010). Jatropha toxicity-a review. Journal of Toxicology and Environmental Health, Part B: Critical Reviews, vol. 13, no. 6, pp. 476-507.

[5] Lin, J., Zhou, X., Wang J., et al. (2010). Purification and characterization of curcin, a toxic lectin from the seed of Jatropha curcas. Preparative Biochemistry \& Biotechnology, vol. 40, no. 2, pp. 107-118. 
[6] Moniruzzaman, M. A., Yaakob, Z., and Aminul Islam, A. K. M. (2015). Potential uses of Jatropha curcas. In: Jatropha Curcas: Biology, Cultivation and Potential Uses, pp. 45-96. New York, NY: Nova Science Publishers Inc.

[7] Dada, E. O., Ekunday, F. O., and Makanjuola, O. O. (2014). Antibacterial activities of Jatropha curcas (LINN) on coliforms isolated from surface waters in Akure, Nigeria. International Journal of Biomedical Science, vol. 10, no. 1, pp. 25-30.

[8] Khan, F., Khan, R. H., Sherwani, A., et al. (2002). Lectins as markers for blood grouping. Medical Science Monitor, vol. 12, pp. 293-300.

[9] Bradford, M. M. (1976). Rapid and sensitive method for the quantitation of microgram quantities of protein utilizing the principle of protein-dye binding. Analytical Biochemistry, vol. 72, pp. 248-254.

[10] Konozy, E. H. E. (2012). Characterization of a D-Galactose-binding lectin from seeds of erythrinalysistemon. Turkish Journal of Biochemistry, vol . 1, pp. 7-18.

[11] Wingfield, P. (2001). Protein precipitation using ammonium sulfate. Current Protocols in Protein Science, Appendices 3 and 3F.

[12] Osman, M. E. M., Awadallah, A. K. E., and Konozy, E. H. E. (2016). Isolation, purification and partial characterization of three lectins from tamarindusindica seeds with a novel sugar specificity. International Journal of Plant Sciences, vol. 6, pp. 13-19.

[13] Awadallah, A. K., Osman, M. E., Ibrahim, M. A., et al. (2017). Isolation and partial characterization of 3 nontoxic d-galactose-specific isolectins from seeds of Momordica balsamina. Journal of Molecular Recognition, vol. 30, pp. 2.

[14] Mohamoud, A., Safinasz, A. F., Ahmed, A. T., Nashwa, M. R. (2015). Antifungal Activity of Lectins against the Fungi F. Oxysporum, Glob Adv Res. J. Microb. Vol. 4, pp. 87-97.

[15] De Oliveira Dias, R., Dos Santos Machado, L., Migliolo, L., et al. (2015). Insights into animal and lectins with antimicrobial activities. Molecules, vol. 20, pp. 519-541.

[16] Al-Saman, M. A., Safinaz, A. F., Tayel, A., et al. (2015). Bioactivity of lectin from Egyptian Jatropha curcas seeds and its potentiality as antifungal agent. Global Advanced Research Journal of Microbiology, vol. 4, no. 7, pp. 87-97.

[17] Ramteke, A. P. and Patil, M. B. (2005). Purification and characterization of Tridax procumbens calyxlectin. Biosciences Biotechnology Research Asia, vol. 3, no. 1, pp. $103-110$.

[18] Santana, S. S., Gennari-Cardoso, M. L., Carvalho, F. C., et al. (2014). Eutirucallin, a RIP-2 type lectin from the latex of Euphorbia tirucalli L. presents proinflammatory properties. PLOS ONE, vol. 9, no. 2, e88422. 
[19] Nsimba-Lubaki, M., Peumans, W. J., and Carlier, A. R. (1983). Isolation and partial characterization of a lectin from Euphorbia heterophylla seeds. Biochemical Journal, vol . 215, no. 1, pp. 141-145.

[20] Juan, L., Xin, Z., Jinya, W., et al. (2010). Purification and characterization of curcin, a toxic lectin from the seed of Jatropha curcas. Preparative Biochemistry \& Biotechnology, vol. 40, no. 2, pp. 107-118.

[21] Aruna, A. J., Shubhangi, K. P., Rajani, G. T., et al. (2016). Isolation and characterization of lectin from the leaves of Euphorbia tithymaloides (L.). Tropical Plant Research, vol. 3, no. 3, pp. 634-641.

[22] Souza, M. A., Amâncio-Pereira, F., Cardoso, C. R. B., et al. (2005). Isolation and partial characterization of a D-galactose-binding lectin from the latex of Synadenium carinatum. Brazilian Archives of Biology and Technology, vol. 48, no. 5, pp. 705-716.

[23] Aumiev, A. K., Cuhatdullin, I. I., Baimev, A. K. h., et al. (2007). Site directed mutagenesis of sugar binding lectin fragment of legume plant with the help of inverse PCR. Molekuliarnain Biology, vol. 41, pp. 940-942.

[24] Mukhammadiev, R. S. and Bagaeva, T. V. (2015). Fungal lectins of fusarium and the dynamics of their formation. Research Journal of Pharmaceutical, Biological and Chemical Sciences, vol. 6, no. 6, pp. 1769-1775.

[25] Shaista, R., Qadir, S., Hussain, I., et al. (2014). Purification and partial characterization of a fructose-binding lectin from the leaves of Euphorbia helioscopia. Pakistan Journal of Pharmaceutical Sciences, vol. 27, no. 6, pp. 1805-1810. 